\title{
An Overview of MSME Sector in India with Special Reference to the State of Uttarakhand
}

\author{
Simranjeet Kaur Virk ${ }^{1}$, Pinnacci Negi ${ }^{2}$ \\ 1Student, Bachelors of Business Administration, ${ }^{2}$ Assistant Professor, Department of Management Studies, \\ ${ }_{1,2}$ Graphic Era Deemed to Be University, Dehradun, Uttarakhand, India
}

\begin{abstract}
MSMEs, considered as "Engines of Growth" are crucial for the economy of developing countries like India due to its potential of creating vast employment opportunities. This Sector has caught the attention of policy makers as it is labour intensive and has the potential of reducing the problem of regional imbalances, ensure financial independence of rural people and assist in sustainable development. The Micro, Small and Medium Enterprises in India is being largely viewed as vital to the economic growth of the country in the 21st century. The present paper will focus on existing scenario and trends of MSME in India. This paper studies the current status of MSME sector in India, its performance, various initiatives taken by the government to accelerate the growth of this sector, as well as the problems faced by the MSMEs in Indian economy. Additionally, this paper dedicates one section to the MSMEs sector in the state of Uttarakhand. The State of Uttarakhand is facing the dire problem of intense migration of people from the hilly terrain particularly due to lack of employment opportunities in the rural areas of Uttarakhand and Uttarakhand badly needs sustainable and inclusive industrial growth of all sub regions of the state. Hence, this paper also analyses the status of MSMEs in the state of Uttarakhand and outlines the problems faced and also recommends the measures that should be taken to promote this sector. The study is a review which was conducted with the help of secondary data retrieved from MSME Annual Reports, other government reports, newspapers and research papers.
\end{abstract}

Keywords: MSMEs, India, Uttarakhand, micro, small and medium Enterprises, Indian Economy

\section{INTRODUCTION}

MSME is an exclusive sector of Indian economy which overlooks the micro, small and medium enterprises leading to an increase in the scale of growth. (www.msme.in) Being a crucial and integral part of Indian economy and commerce these enterprises are also associated with entrepreneurship and development of entrepreneurs in India. Concept of MSME in regard to governmental policies is directly linked to the entrepreneurs. Governmental policies related to MSMEs in India can be complex but may be very effective in elimination of poverty and increase income level leading to development of entrepreneurial sector. Understanding the concept and extraction of business benefits from this concept can be proved as an effective tool for the development of budding as well as existing entrepreneurs in India. Moreover, as per the government of India (www.gov.in) MSME is nowadays seen as an added nutrition to the Indian scale of growth and development. However, Dhangi, 2014 in a study mentioned in an international journal says that MSMEs are the essence of growth of economy in India as well as worldwide and women are also getting due recognition in this sector.

In this paper we will study about background MSME its definition as per the view of government of India and the Reserve bank of India in the first section. Succeeding this section, the current profile of MSME in India along with our state Uttarakhand and various schemes in regard to MSME are elaborated. Following the continuum we will have an insight of performance of MSME and problems related to prospects of MSME occurring due to various hindrances in pathway of MSME.

\section{DECODING MSME:}

MSME stands for Micro Small \& Medium Enterprises governed by MSMED (Micro Small \& Medium Enterprise
Development) Act 2006. As per the explanation of the Development Commissioner pertaining to the Ministry of Micro Small \& Medium Enterprises it is one comprehensive act that supervise the regulation of small enterprises along with a focus on their development at wider lens that are not that big giant players in the market economy. There had been a demand of this sector for such an act to be passed to set the sector free from the tangles of the laws and regulations and the visits of inspectors which the sector was facing with limited resources and lack of awareness, hence the aim was to recommend and provide a legitimate framework for small sector to give small sector a relief from compliance to bunch of laws and rules. (www.ma-cs.com )

\section{DEFINING MSME:}

As the government of India enacted the MICRO SMALL \& MEDIUM ENTERPRISE DEVELOPMENT ACT in 2006 , (www.rbi.org.in / www.gov.in) the micro small and medium enterprises were defined in terms of the enterprises engaged in the manufacturing of goods and rendering services. Categories for these enterprises were brought into the form as follows:

As per the year 2006 the classification of MANUFACTURING industries was given as follows:

\begin{tabular}{|l|l|l|}
\hline Category & $\begin{array}{c}\text { Manufacturing } \\
\text { Industry } \\
\text { (Investment in Plant } \\
\text { and Machinery) }\end{array}$ & $\begin{array}{l}\text { Service Industry } \\
\text { (Investment in } \\
\text { Equipments) }\end{array}$ \\
\hline MICRO & $\begin{array}{l}\text { Not exceeding rs. 25 } \\
\text { lakhs }\end{array}$ & $\begin{array}{l}\text { not exceeding rs. } \\
\text { 10 lakhs }\end{array}$ \\
\hline SMALL & $\begin{array}{l}\text { Between rs. 25 lakhs } \\
\text { to 5 crores }\end{array}$ & $\begin{array}{l}\text { Between rs. 10 } \\
\text { lakhs to 2 crores }\end{array}$ \\
\hline MEDIUM & $\begin{array}{l}\text { Between rs. 5 crores } \\
\text { to 10 crores }\end{array}$ & $\begin{array}{l}\text { between rs. 2 } \\
\text { crore to 5 crore }\end{array}$ \\
\hline
\end{tabular}


As per the amendment in the act in February, 2018, (www.indianeconomy.net) the current design for the MSME distribution on the basis of annual turnover of the manufacturing and the service industries is as follows :

\begin{tabular}{|c|c|}
\hline CATEGORY & $\begin{array}{c}\text { CLASSIFICATION ON THE BASIS } \\
\text { OF ANNUAL TURNOVER OF THE } \\
\text { MANUFACTURING AND } \\
\text { SERVICE INDSTRY }\end{array}$ \\
\hline MICRO & Not exceeding rs. 5 crore \\
\hline SMALL & Between 5 crore to rs. 75 crore \\
\hline MEDIUM & Between 75 crore to 250 crore \\
\hline
\end{tabular}

This was is the new classification of micro, small and medium enterprises which is based on the value of the annual turnover of the industry. It was proposed and applied by the Government from February 2018.

MSMEs are a device of growth for our country. Near about $90 \%$ share of total enterprises is occupied by MSMEs in India and to stimulate the growth of the nation MSMEs need to be empowered, educated and and directed towards the optimum resource utilization to harness the best results (Shiralashetti,2012)

\section{CURRENT STATUS AND PERFORMANCE OF MSME SECTOR IN INDIA:}

MSMEs play a vital role in the expansion of entrepreneurship scale by contributing various innovative means. Now, in the present era, MSMEs are reaching new heights, (annual report 2017-2018) MSMEs are now having a global reach from India by entering the diverse markets and by capturing a wider share worldwide. The micro, small and medium industries have been great contributor in the gross value added and the gross domestic product of our economy i.e, GVA and GDP.

Mentioned in the annual report of our country corresponding to the year 2017-2018 released by the Ministry of micro small and medium enterprise (Government Of India), the data provided by Central Statistics Office (CSO), Ministry of statistics \& programme Implementation the contribution of micro, small and medium firms in the gross value added and the gross domestic product have been as follows:

CONTRIBUTION OF MSMES IN COUNTRY'S ECONOMY BASED ON CURRENT PRICES is elaborated as follows: (http://msme.gov.in)

\begin{tabular}{|c|c|c|c|c|c|c|}
\hline Year & $\begin{array}{c}\text { Msme Gross } \\
\text { Value Added }\end{array}$ & $\begin{array}{c}\text { Growth } \\
\%\end{array}$ & $\begin{array}{c}\text { Total Gross } \\
\text { Value } \\
\text { Added }\end{array}$ & $\begin{array}{c}\text { Share of Msme } \\
\text { in Gross Value } \\
\text { Added }\end{array}$ & $\begin{array}{c}\text { Total Gross } \\
\text { Domestic } \\
\text { Product }\end{array}$ & $\begin{array}{c}\text { Share of Msme in } \\
\text { Gross Domestic } \\
\text { Product (in \%) }\end{array}$ \\
\hline $2011-2012$ & 2583263 & - & 8106946 & 31.86 & 8736329 & 29.57 \\
\hline $2012-2013$ & 2977623 & 15.27 & 9202692 & 32.36 & 9944013 & 29.94 \\
\hline $2013-2014$ & 3343009 & 12.27 & 10363153 & 32.26 & 11233522 & 29.76 \\
\hline $2014-2015$ & 3658196 & 9.34 & 11481794 & 31.86 & 12445128 & 29.39 \\
\hline $2015-2016$ & 3936788 & 7.62 & 12458642 & 31.60 & 13682035 & 28.77 \\
\hline
\end{tabular}

The above mentioned report shows that the contribution of MSMEs have been around approximate figure of $33 \%$ i.e, almost one third of third of the total gross value added and the share of MSMEs have been nearly 30\% in the total gross domestic product. This shows that MSMEs have captured a good part as a major determinant of the national economy during these 5 years mentioned in the latest annual report.(www.msme.in )

\section{MEASUREMENT OF THE PERFORMANCE OF MSMES IN INDIA:}

There are some resources mentioned below are the key determinants that show the performance of micro small and medium sector of India highlighted by latest annual report by government of India(Annual report 2017-2018), on micro small and medium enterprises of the year 2017-2018 (www.msme.gov.in)

NATIONAL SAMPLE SURVEY, the $73^{\text {rd }}$ round of the national sample survey based on the unincorporated non-agricultural enterprises in manufacturing, trade and other service sectors (except construction) expose the latest account of the MSME sector performance as the estimated number of 633.92 lakh enterprises only 4000 were large and thereby out of MSME sector. (www.msme.gov.in)

One more indicator of performance of MSME sector is the report of the economic census created by the central statistics office which is the REPORT OF 6 $^{\text {TH }}$ ECONOMIC CENSUS which is majorly seen for the detailed data collection mainly of non-agricultural sector of economy, this census has been conducted in 2013-14 as the latest census, and this report says that 58.5 million establishments were found to be in operation whereas 34.8 million (which means $59.48 \%$ ) establishments were found in the rural areas and the rest 23.7 million (which means $40.52 \%$ ) establishments were found as located in the urban areas. (www.msme.gov.in)

(http://msme.gov.in) Micro small and medium enterprise sector have an active participant in the economic growth and development leading various new set ups and occupying a huge share in the total commercial units. MSMEs have also put a great hand in uplifting the rural sections by pulling them up to the level of a great economic value and we can made it evident by the complementing the economic census report.

Kumar \& Sardar, 2012 also highlight the importance of micro small and medium enterprises by quoting the efficient and diversified performance of MSMEs in India by amplifying the industrial growth. They mentioned the nature of MSMEs as the more labour intensive and less capital intensive. MSMEs have also been an important sector of employment for the rural India and the measure of removing unemployment from the urban India.

Indian economy is abundant of demand due to co existence of variety and diversity to a large extent creating a path for MSME sector to grow and come up with a stage for new 
innovations and inventions. This is a core feature which is helpful in seeking and maintaining the balance in the economy and enhancement in the growth by micro small and medium firms or enterprises. MSME sector have also been performing the role of a great opportunity as well as a platform of development for entrepreneurs leading to a rise in entrepreneurial development

\section{INITIATIVES UNDER MSME ACT IN INDIA:}

$>$ As per the amended MSME act, there are several initiatives taken up by the government of India for the sake micro small and medium sector enterprises. Under this light, recent steps inclusive of tax concessions in the budget with regard to the micro small and medium enterprises with aim of conversion and transformation in the MSME sector with a numeral of 6.33 crore for making MSME a growth booster sector to Indian economy referring "new India" (m.economictimes.com).

$>$ The launch of digital MSME scheme rotating on the point of cloud computing that comes up as an economic way of alternating IT infrastructure installed by micro small and medium enterprises to manage their business processes in a more effective manner(www.pib.nic.in).

$>$ During the year 2015, the government of India, Ministry of micro small and medium enterprises, has taken many initiatives and one of them to be very effective and efficient with regard to the entrepreneurship development was regarding the ease of doing business. In this year a very big initiative related to business development was taken (www.gov.in). In this initiatives over 95,000 aadhar memorandums were filed regarding the ease of doing business. (www.msme.gov.in). This lead to making of the micro small and medium enterprises competitive at global level. It included ease of registration of the business in the form of aadhar memorandum, it also aimed at uplifting the MSMEs which went sick during the past times.. (www.pib.nic.in This resulted in promotion of the in I rural entrepreneurship and it also came out with new innovative ideas for expansion of the MSME sector. (www.udyogaadhar.gov.in) This was ASPIRE SCHEME of the government that came up with financial help as in the form of credit guarantee ). This was implemented by udyog adhar memorandum addressed by Shri kalraj mishra, the on date minister of micro small and medium enterprises, on $6^{\text {th }}$ October, 2015 along with the secretary minister of micro small and medium enterprises and steel, Dr. Anup K. Pujari and the director general $(M \& C)$ and the Press information officer shri A.P. frank naronha. ( www.pib.nic.in ).

$>$ During the year 2018 prime minister shri narendra modi also took a very big initiative of launching historic support and outreach initiatives for MSME sector. In this initiative the prime minister also exposed the 12 major decisions targeted towards the growth and development, ease of the working of MSMEs and facilitating the expansion of micro small and medium enterprises. (www.msme.gov.in ).

Prime minister shri narendra modi also revealed that the fruitful results of the MSME schemes in India can be precisely understood by the achievement of our country of rising from the rank of 142 to the rank of 77 in the "ease of doing business rankings" in the last four years. (www.msme.in). Prime minister highlighted the 5 key aspects that are necessary for the sake or the efficiency of the MSME sector. They are basically an easy access to credit, easily accessible market, an efficient and upgraded technology, ease of doing business and the sense of social security and belongingness of employees (www.pib.nic.in). These 12 major steps were elaborated by the honourable prime minister as follows:

$>$ The first announcement was related to the credit facility itself. In this a 59 minute loan portal has been introduces by the prime minister. According to the prime minister, a loan credit of upto the principle of rs. 1 crore to MSMEs can be granted with the help of this portal in just 59 minutes. This would be great support for MSMEs in India. (www.pib.nic.in )

$>$ The second announcement was introduced as a subvention of $2 \%$ interest for all GST registered MSMEs.(www.pib.nic.in )

$>$ The third declaration was to bring all the companies with a turnover of more than 500 crore into the trade receivables e-discounting system (TReDS) facilitating the easy credit facility for entrepreneurs (www.pib.nic.in).

$>$ The fourth statement, made by the prime minister focus upon the factor of market access. This enables a new guideline for the public companies to make $25 \%$ of their total purchase instead of $20 \%$ from the MSMEs. (www.pib.nic.in)

The fifth key decision was that the women entrepreneurs. It was about reservation of $3 \%$ procurement from women entrepreneurs out of total $25 \%$ procurement by public companies mentioned in the previous announcement.(www.pib.nic.in)

Sixth announcement was that all the public sector undertakings of the central government must now be registered under GeM as a part and parcel of GeM. (www.pib.nic.in)

Seventh declaration was that 20 hubs along with 100 spokes in form of the tool rooms will be established across the country. This was on enhancement of the technology. (www.pib.nic.in)

$>$ Eight statement was on ease of doing business pointing the groups or the bunches to be formed of pharma MSMEs and the $70 \%$ share of the expenses of establishing these clusters will be borne by the central government.(www.pib.nic.in).

$>$ The ninth announcement was on labour law taking into consideration that the return as per 8 labour laws and 10 union regulation must now be filed only one time in an year. (www.pib.nic.in).

$>$ Tenth announcement was noted that establishments' inspector for the visit will be decided randomly by computer system. (www.pib.nic.in).

$>$ In the eleventh announcement, prime minister said that, under air pollution and water pollution laws have been merged as a common and single consent only.(www.pib.nic.in).

$>$ In the twelfth statement, the prime minister mentioned about the ordinance brought under which the entrepreneurs will no longer have to approach the couts for minor violations under the companies act, but can be solved out by simple procedures.(www.pib.nic,in).

Moreover apart from these factors, prime minister also talked about the employees' social security. He said that mission will be launched to ensure that all the employees are holding Jan dhan accounts, provident funds and insurance to make sure that the employees in MSMEs are able to harness the benefits and are socially secure (www.pib.nic.in ). 


\section{PROBLEMS RELATED TO MSMES IN INDIA:}

Dr. Sultan Singh Jaiswal (2014) in his study in international journal of innovation and research says that the MSME sector plays a vital role in the economical growth but according to the report of subgroups on unorganised sector (which was the group working on MSMEs growth during the $12^{\text {th }} 5$ year plan of our economy) it could be observed that due to diversity and and heterogeneity in the MSME sector, there can be many obstacles and problems across the way of MSMEs.

Some of the common problems as studied by Jaswal, 2014 that can be faced by the MSMEs can be observed as follows:

There can be some challenging situations faced by the MSMEs as highlighted by the prime minister mentioned earlier in the paper i.e., problem of availability of credit facilities , problem of market access, issues related to the infrastructure, obstacles in way of access to people and problem of access to technology, environmental threats and the issue of effective regulation.

Moreover, the other challenges faced by the MSMEs can be the following ones:

Mortgage requirements, issue of accessibility to the equity capital, problems of supply to government departments, warehousing problems, lack of efficient manpower, multiple labour laws hindering and making the labour work more casual, taxation and direct or indirect burdens and obligations may also be a constraint for the business.

So, the above mentioned problems are some hurdles in the way of MSMEs to work however the initiatives and schemes are being introduced since years meant to curb these issues making it mote flexible and reducing the complexities.

\section{MSME SECTOR IN UTTRAKHAND:}

Uttarakhand is a state which is abundant in terms of resources as well it carries enough characteristics and conditions which are required for setting up and running an industry

According to Patra \& Chaubey ,2014 the best and most attractive factor for the entrepreneurs is the benefits that they get out of the business they do and Uttrakhand is an indication which clarifies that natural and climatic factors of uttrakhand state attracted most of the entrepreneurs to set up and run their business here. The analysis also states that there are various facilities which are an attraction for the business units. Uttrakhand have some very beneficial nutrients such as good power supply and better water facilities as compared to some other northern states. Moreover, the facilities regarding the subsidies and the concession, training for entrepreneurial activities, land resources , marketing space, schemes related to upgrading technology are such factors that attract the entrepreneurs to uttrakhand and that work as a helping hand in entrepreneurial development. On the flip side, the shortage of suitable manpower and some market obstacles like lack of proper exploration may be responsible for hindered performance of business. (www.dcmsme.gov.in).

So we can say that, Uttrakhand is rich source of bioresources and carries extremely good climate due to presence of the adequate natural characteristics. Rich flora and fauna gives rise to new doors being opened welcoming new projects and business ideas to be executed in its rich boundaries. Adequate water and power supply give reliance to the business firms for a better work and hence MSMEs do have a positive support in uttrakhand,

Districts of uttrakhand are also benefitted by various schemes and government plans and policies giving an advantage to MSMEs which is also a favourable sign related to entrepreneurial development. As per the recent analysis of 2018, it is obtained that almost all the districts of uttarakhand have been benefitted by the MSME sector and the industrial sector have also been growing in the MSME sector. (www.smeventure.com)

The MSME policy of Uttarakhand is an offering related to small \& medium enterprises regarding few incentives such as interest subsidy and VAT (value added tax) reimbursement, capital investment subsidy that would be seen in the form till $31^{\text {st }}$ of march, 2020, whereas the benefits can be extracted from incentives till $31^{\text {st }}$ march 2025. (www.doiuk.org)

The primary objective of the micro small and medium enterprises in the state is to move one thousand young people to up business visions in a consistent manner. However, two small scale material parks are also set up in the pithoragarh districts and the chamoli district at munsiyari and bhimtalla respectively. The aim is promoting and propagating investment and making the state an industrial hub. Moreover, the target is to enhance the use of local and domestic capital leading to more employment opportunities reducing the condition of unemployment in the state and uplifting the hidden talent through talent education which is not being utilised to its best level. The administration aims at accomplishing the mentioned objectives till the year 2020. (www.smeventure.com)

The State of Uttarakhand is divided into 13 districts, i.e. Nainital, Udham Singh Nagar, Almora, Pithoragarh, Champawat, Bageshwar, Chamoli, Uttarkashi, Rudraprayag, Dehradun, Pauri, Tehri and Haridwar.

According to Industry Association of Uttarakhand (IAU), more than 19,000 registered micros, small and medium enterprises (MSMEs) causing an estimated Rs531.20 crores loss to the sector, were hit in the natural disaster which ruined the Uttarakhand State in 2013. The types of business activities which were affected due to floods include Pharmaceuticals, Hotel Industry, Tour \& Travel operator, Eateries, Cabs, Food Processing, Agriculture, Tourism Industry, Hotel Restaurant, Fabrication, Handloom and handicrafts. Since then, the overall growth rate of MSMEs in Uttarakhand has not been remarkable.

Table1

\begin{tabular}{|l|c|c|l|}
\hline \multicolumn{4}{|c|}{ Distribution of no. of SME Enterprises and Employment in Uttarakhand } \\
\hline & REGISTERED SECTOR & UNREGISTERED SECTOR & TOTAL \\
\hline NO. OF ENTERPRISES & 0.24 lakhs & 3.51 lakhs & 3.75 \\
\hline EMPLOYMENT & 0.8 lakhs & 6.16 lakhs & 6.96 \\
\hline \multicolumn{4}{|c|}{ Distribution of Principle Characteristics of SME sector } \\
\hline & Enterprises & Employment & $\begin{array}{l}\text { Market Value of } \\
\text { Fixed Assets }\end{array}$ \\
\hline & 2.23 lakhs & 4.42 lakhs & 6014.98 crores \\
\hline Uttarakhand & Source: Annual report 2014-15, Ministry of MSME, New Delhi \\
\hline
\end{tabular}




\section{Incentives for MSME sector in Uttarakhand}

Hill policy of 2008 was meant for uplifting the backward areas particularly in the hilly terrains. It was brought for employment to the youth belonging to the backward regions giving rise to the MSMEs in the state.

However, the industries were classified as green and orange category which were understood as the non-polluting industries and this scheme was applicable to the industries of this category only.

In May 2015, the schemes that were elaborated by the state directorate of industries, Dehradun, are as follows :

Subsidy on capital investment, interest and reimbursement of value added tax were there till 31 march, 2020, but the failures that would have been faced under the scheme can be recovered till the year 2025.

Districts of the state were divided into four broad categories named as A, B ,C and D for a better and clear understanding of the policy and its implementation wherein, the industries belonging to category A were considered as the most backward and the industries of category D were assumed as the most developed industries.

The subsidy distribution for the different industries was as follows:

\begin{tabular}{|c|c|c|c|c|}
\hline Subsidy & $\begin{array}{c}\text { Category } \\
\text { A }\end{array}$ & $\begin{array}{c}\text { Category } \\
\text { B }\end{array}$ & $\begin{array}{c}\text { Category } \\
\text { C }\end{array}$ & $\begin{array}{c}\text { Category } \\
\text { D }\end{array}$ \\
\hline $\begin{array}{c}\text { Investment } \\
\text { subsidy }\end{array}$ & $40 \%$ & $35 \%$ & $30 \%$ & Int $15 \%$ ati \\
\hline $\begin{array}{c}\text { Interest } \\
\text { subsidy }\end{array}$ & $10 \%$ & $8 \%$ & $6 \%$ & Of Trend \\
\hline
\end{tabular}

Some policies formulated by department of MSMEs along with the industries association of Uttarakhand also focussed on development of the infrastructure, cluster development and schemes of union were also up for building small rooms to build up a land bank to provide concession to MSMEs on land. It also aimed at affective training and skill development of the young employees.

Other incentives such as E-office for paperless work, national portal for filing of EM-I \& EM-II, virtual cluster portal for common applications and credit scoring models at msmevirtualcluster.in and B2C web portal of NSIC have also been launched for the sake of MSMEs. An Employment Facilitation Portal set up by NIESBUD was launched by the Minister (MSME) on 11th July, 2014. The government has placed all the forms and guidelines of the schemes implemented by the Ministry on its website. Online applications have been introduced for most number of schemes.

\section{Problems faced by MSMEs in Uttarakhand}

UTTRAKHAND has been facing some crucial problems since last few decades that are responsible for hindering the performance of MSMEs in the state. Some of them are mentioned below;

$>$ There is a problem of effective marketing and selling in the state due to uneven geographical factors.

$>$ Inadequate Infrastructure

$>$ Lower technology levels

$>$ The industries are heavily weighed down by the rules and regulation imposed on them.
$>$ There is a shortage of financial benefits and capital investment in the MSME sector

$>$ Shortage of energy leading to high energy cost is also an issue.

$>$ Problems of storage, designing, packaging and product display

$>$ Youth of the state lacks in proper skill development and training.

$>$ Lack of proper research and development is also an issue.

\section{Recommendations for boosting the growth in the MSME} sector of Uttarakhand

Following steps may augment the formation and position of MSME in the State:

$>$ Following Cluster Development Approach may be beneficial for enhancing sustainable growth in MSME sector.

$>$ Strengthening Training Institutions and training facilitation in the rural and remote areas;

$>$ Providing Better marketing assistance to MSMEs and bolstering /creation of existing/new marketing support infrastructure or institutions.

$>$ Rural Outreach Programme can help boost this sector, with faculty and students of academic institutions sharing their knowledge, ideas and resources with the msme units.

Introduction of a Public Procurement Policy for MSMEs for assisting the MSMEs in expanding their market share.

The principal sources of technological innovations are the academia, R\&D organisations, individual innovators, etc. The key challenge, however, is technology transfer which will foster innovation, technology entrepreneurship and above all, opportunities to SMEs to attempt highrisk pre-proof-of-concept R\&D.

$>$ Encouraging innovations through setting up of large number of business incubators in educational institutions of repute and providing skill training to unemployed youths in the State

Introducing Micro-credit schemes particularly for service sector micro units can play a key role in poverty reduction and regional development.

> Operationalising a scheme for supporting the States to set up Rehabilitation Funds and launch suitable schemes for the rehabilitation of enterprises temporarily rendered sick due to no particular fault of theirs.

\section{CONCLUSION}

MSMEs are termed as the "engine of economic growth" of any country both developed and developing but specially developing countries. It's the panacea to alleviate poverty and also a proven way to improve the quality of life particularly for the poor people. Uttarakhand is facing the severe problem of migration of people from hills to the plains in pursuit of better employment opportunities. This has led to the creation of many ghost villages up hills and severe stress on resources and infrastructure in the plain areas. If we wish to curtail this trend in the hill regions, creation of adequate employment opportunities in MSMEs is critical. MSMEs have the potential to act as catalysts of growth and thus curb this societal crisis. The State should strive for MSME penetration across all the thirteen districts to ensure an overall development of the state. Also, the Uttarakhand Government needs to provide adequate support and take certain protectionist measures in order to allow the MSME develop to its full potential in the state. 
International Journal of Trend in Scientific Research and Development (IJTSRD) @ www.ijtsrd.com eISSN: 2456-6470

\section{References}

[1] Dangi, N. (2014). Women entrepreneurship and growth and performance of MSMEs in India. International Journal, 2(4) 174-182.

[2] Jaswal, S. S. (2014). Problems and Prospects of Micro, Small \& Medium Enterprises (MSME's) in India. International Journal of Innovative Research \& Studies, 3(5), 140-161.

[3] Kumar, N. K., \& Sardar, G. (2011). Competitive Performance of Micro, Small and Medium Enterprises in India. Asia Pacific Journal of Social Sciences, 3(1), 128-46.

[4] Patra S \& Chaubey D.S, (2014). Factors Influencing Industrial Performance: An empirical Study with Special reference to The MSMEs of Uttarakhand State. IMJT Vol. 22 No., (12-28).

[5] Pathak P \& Agarwal M. (2017) Evaluation of Growth and Performance of Micro, Small and Medium Enterprises: A Study of Uttarakhand Region, India. IJAR 4(6) 554-562.

[6] Shiralashetti, A. S. (2012). Prospects and Problems of MSMEs in India-A Study. International Journal of in Multidisciplinary and Academic Research, 1(2), 1-7.

\section{Electronic Sources:}

[1] www.msme.gov.in.

[2] http://en.m.wikipedia.org/wiki/MinistryofMicro,smalla ndMediumEnterpreises
[3] www.dcmsme.gov.in.ssindia/definationmsme.htm

[4] www.mass.gov/renting-in-massachusetts

[5] www.smeventure.com/impact-of-government-policieson-sme-sector

[6] www.rbi.org.in/commomperson/english/scripts/faqs.a spx

[7] http://dcmsme.gov.in/ssindia/msme_in.htm

[8] http://www.smeventure.com/highlights-msme-policyuttarakhand/

[9] http://doiuk.org.mysite/newsandevents

[10] http://msms.gov.in/all-schemes

[11] www.smeventure.com/familiar-10-major-initiativestaken-towards-msme-indian-governemnt

[12] http://pib.nic.in/newsite

[13] www.phdcci.in „Study on The Emerging Contours in the MSME sector of Uttarakhand- A survey based empirical study 2014 undertaken by PHD Research Bureau of PHD Chamber of Commerce \& Industry in 2014

[14] http://m.economictimes.com/defaultinterstitial.cms

[15] http://udyogaadhaar.gov.in/UA/UAM_registration.aps $\mathrm{X}$

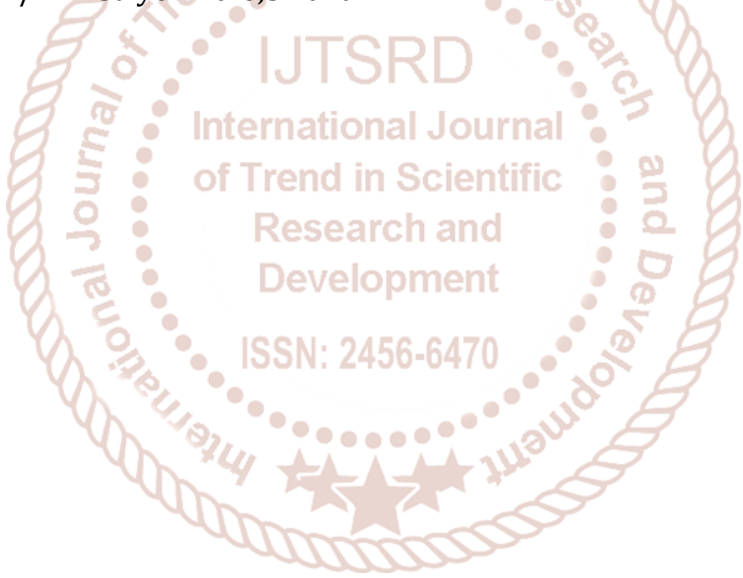

